Journal of Agricultural Sciences
(Tarim Bilimleri Dergisi)

\title{
Pedotransfer Functions for Estimation of Soil Moisture Constants from Penetration Resistance Measurements and Some Soil Properties
}

\author{
Pelin ALABOZ ${ }^{\text {** (i) }}$, Ahmet Ali IŞILDAR ${ }^{\mathrm{a}}(\mathbb{D})$ \\ ${ }^{a}$ Isparta University of Applied Sciences, Department of Soil Science and Plant Nutrition, Isparta, TURKEY \\ ARTICLE INFO \\ Research Article \\ Corresponding Author: Pelin ALABOZ, E-mail: pelinalaboz@isparta.edu.tr \\ Received: 01 October 2019 / Revised: 02 December 2019 / Accepted: 15 December 2019 / Online: 31 May 2021
}

\section{ABSTRACT}

Studies to prediction of soil moisture constants and other soil properties rather than direct measurements were never dwindle importance. Models were derived from other soil properties obtained easily. Therefore, in this study focused on the predictability of some moisture constants, whose determination was often difficult and time-consuming, from penetration resistance measurements. In the improvement of alternative models for the estimation of moisture constants; in addition to penetration resistance, textural fractions (sand, clay and silt), bulk density, $\mathrm{CaCO}_{3} \%$ and organic matter contents were included. The models were created according to soil groups with different textures (sandy, loamy, clay) for moisture constants at $0.1,0.33,0.5$ and 15 bar.
In the models for estimation of $0.1,0.33,0.5$ and 15 bar moisture content, the highest differences in $\mathrm{R}^{2}$ values $(0.61,0.60,0.64$ and 0.59$)$ between the actual and the predicted data was obtained for loamy soils. For this group, the root means square error (RMSE) ranged between 1.32 and $1.90 \%$, and in addition, the mean error (ME) was determined to be in a range from 1.53 to $2.05 \%$. For the estimation of moisture content at different soil moisture tensions using organic matter, bulk density, clay and penetration resistance properties, the coefficient of determination ranged from 71 to $77 \%$. Therefore, it is concluded that the alternative models, developed using penetration resistance or by the addition of some other soil properties, could be used safely in the loamy texture soils.

Keywords: Penetration resistance, Moisture constants, Pedotransfer functions, Soil physics

(C) Ankara University, Faculty of Agriculture

\section{Introduction}

Pedotransfer functions (PTFs) explain the relationships within soil properties, and they have attracted the attention of researchers in recent years. In these studies, some soil properties are estimated indirectly by way of other easily measured soil properties, instead of laborious and time-consuming methods. Thus, it is possible to easily determine properties that are otherwise difficult to predict thanks to these functions. The field capacity and permanent wilting point moisture constants are great importance in determining the optimum amount of water to be used for plants. Bahtiyar (1978) stated that only part of the capillary water, which is associated with a soil moisture tension of 0.31 to 33 atmospheres in the soil can be used by the plants between the field capacity $(0.33 \mathrm{~atm})$ and the permanent wilting point $(15 \mathrm{~atm})$. Field capacity and permanent wilting point determination are very time consuming and laborious in field conditions. Studies where the field capacity and permanent wilting point properties could be estimated by other soil properties (Minasny 2009; Mohanty et al. 2015; Touil et al. 2016) have remained important for many years. When soil properties are examined, some soil features affect many other properties (Turgut et al. 2010; Negiş et al. 2016). Penetration resistance varies depending on many other properties, significant increases have been observed, especially for decreasing moisture content (Busscher 1990; Şeker 1997; Turgut et al. 2008). It was predicted that this property, which is greatly affected by soil moisture content, can be used to estimate soil moisture constants. In this study the focus was on models to estimate some soil properties by using data on other known properties of soil. The penetration resistance values in soils are significantly affected by moisture and the range of this property is wide; it is also easy to determine. The aim was to estimate moisture constants by using penetration resistance values. The use of digital penetrologger, which was a very important approach in determining soil moisture constant, would facilitate the use of the created pedotransfer functions, because the determination of moisture constants take a long time in the laboratory conditions. The penetration resistance value can be determined instantly in the field using digital penetrologger. However, determination of soil moisture constants (field capacity and permanent wilting point) takes between 3-5 days in the laboratory. The main purpose of this study is to determine the moisture constants such as field capacity, permanent wilting point instantly with the penetration resistance value that you determined during the field reading. In addition, the penetration resistance is highly influenced by the soil moisture content. So, this study was designed with the idea that penetration resistance can be used as a variable in the estimation of moisture constants. In this study, models were created according to soil groups with different textures (sandy, loamy, clay) for moisture constants $(0.1,0.33,0.5$ and 15 bar). Alternative models were produced using other 
soil properties (sand, clay silt, bulk density, $\mathrm{CaCO}_{3}$ equivalent and organic matter) in addition to the penetration resistance to investigate the effects of other soil properties on models.

\section{Material and Methods}

The study was carried out over an area of approximately 308,136 hectares of the Atabey, Keçiborlu, Gönen, Eğirdir, Gelendost, Yalvaç and Aksu districts of Isparta province in Turkey. Disturbed and undisturbed surface soil samples (0 to $20 \mathrm{~cm}$ ) were taken in 107 different agricultural fields. At these locations, penetration resistance measurements (PR) were recorded at different moisture levels. Penetration resistance measurements were made in the field and then some soil samples were taken and weighed. Samples were placed in storage containers to determine moisture content and brought to the laboratory. Penetration resistance measurements were performed using penetrologger (Eijkelkamp) in the field. $1 \mathrm{~cm}^{2} \mathrm{base}$ area cone-shaped (Cone $60^{\circ}$, NEN 5140) tip was used for penetration measurements. A representative location in the field was selected and measurements were made there. The soil moisture content was measured across a range spanning from saturated to dry, and the penetration resistance was noted to determine the moisture-penetration resistance relationship in the field. The spring rains were expected to determine moisture levels close to saturation. The field part of the study was completed in 2 years. In the spring rains of the first year, sampling and measurements were made in 50 different field. The remaining 57 field soil measurements was made in the $2^{\text {nd }}$ years. After the excess water was drained in the soil, the penetration resistance measure and soil moisture determinations started and continued to dry after 3 days in the field conditions. After the first measurements, moisture-penetration resistance was monitored at representative location. In order to establish the relationship between moisture and penetration resistance measurements, sampling and measurements were performed 20-30 times at each point. Some physico-chemical analysis were carried out in the soil (disturbed and undisturbed) brought to the laboratory in the first sampling. The soils were divided into groups according to the principles of the Soil Survey Manual (1993) as sandy (S, LS), loamy (SL, L, SiL, Si, CL, SCL, SiCL) and clay (SC, SiC, C) soils. There were determined to be 21 sandy soils, 66 loamy soils and 20 clay soil groups. Soil moisture content at $0.1,0.33,0.5$ and 15 bar, and some of their physical and chemical properties were investigated (Table 1). The moisture content was determined by gravimetric (M) and volumetric $(\Theta)$. The average moisture content $(\mathrm{am})$, specific to a texture group, was found for each tension pressure $(0.1,0.33,0.5$ and 15 bars). The penetration resistance values (PRam), which correspond to the average moisture (am), for the soil in the group, were determined using the PR-moisture graph of the soil. Then, the PRam values of soils in the same group, and the actual moisture values $(M)$ maintained at that pressure were associated (PRam $-M$ ) to obtain the prediction model. In order to express the penetration resistance measurements made at different moisture levels against a standard moisture level (am), the moisture-PR data were associated with all soils in each soil group. These relationships were used in the determination of the PR corresponding to the standard moisture $(\mathrm{am})$, when implementing the estimation models. Then, moisture correction equations were included in the basic model to obtain the prediction models. In addition, the use of textural fractions (sand, silt, clay) and some other soil properties $\left(\mathrm{CaCO}_{3}\right.$, organic matter and bulk density) were also investigated for the prediction of moisture constants.

Table 1- Soil properties used in the models

\begin{tabular}{|c|c|c|c|c|c|c|c|c|c|c|c|c|c|}
\hline $\begin{array}{c}\text { Soil } \\
\text { group }\end{array}$ & & $\begin{array}{c}B D \\
\mathrm{gr} \mathrm{cm}^{-3}\end{array}$ & $\begin{array}{c}\text { Clay } \\
\%\end{array}$ & $\begin{array}{c}\text { Silt } \\
\%\end{array}$ & $\begin{array}{c}\text { Sand } \\
\%\end{array}$ & $\begin{array}{l}0.1 \\
\text { bar } \\
(\%)\end{array}$ & $\begin{array}{l}0.33 \\
\text { bar } \\
(\%) \\
\end{array}$ & $\begin{array}{l}0.5 \\
\text { bar } \\
(\%)\end{array}$ & $\begin{array}{l}15 \\
\text { bar } \\
(\%)\end{array}$ & $\begin{array}{c}\mathrm{CaCO}_{3} \\
\%\end{array}$ & $\begin{array}{c}O M \\
\%\end{array}$ & $p H$ & $\begin{array}{c}E C \\
\mu \mathrm{mhos} \\
\mathrm{cm}^{-1}\end{array}$ \\
\hline \multirow{3}{*}{ Sandy } & Min. & 1.30 & 4.80 & 7.55 & 78.00 & 12.71 & 9.40 & 8.04 & 4.06 & 0.86 & 0.79 & 5.37 & 67 \\
\hline & Max. & 1.58 & 10.71 & 16.65 & 86.74 & 17.74 & 14.53 & 11.88 & 7.35 & 3.95 & 1.85 & 7.86 & 696 \\
\hline & Mean & 1.40 & 6.77 & 11.31 & 81.91 & 14.98 & 12.12 & 10.22 & 5.47 & 2.17 & 1.18 & 7.36 & 173 \\
\hline \multirow{3}{*}{ Loamy } & Min. & 1.21 & 5.47 & 4.90 & 10.87 & 14.52 & 11.17 & 9.65 & 6.04 & 1.29 & 0.87 & 6.63 & 101 \\
\hline & Max. & 1.55 & 34.92 & 70.41 & 76.53 & 29.29 & 27.43 & 25.12 & 16.78 & 45.27 & 3.92 & 8.38 & 1236 \\
\hline & Mean & 1.35 & 23.72 & 30.11 & 46.17 & 23.68 & 20.71 & 18.84 & 11.24 & 15.19 & 1.97 & 7.70 & 350 \\
\hline \multirow{3}{*}{ Clay } & Min. & 1.13 & 40.32 & 13.48 & 9.37 & 26.47 & 22.67 & 19.15 & 12.9 & 3.23 & 1.39 & 7.45 & 156 \\
\hline & Max. & 1.49 & 49.49 & 43.39 & 38.8 & 32.84 & 28.99 & 27.65 & 18.77 & 44.88 & 3.5 & 8.3 & 725 \\
\hline & Mean & 1.32 & 42.88 & 32.14 & 25.08 & 29.69 & 26.44 & 23.82 & 15.13 & 18 & 2.12 & 7.73 & 389.8 \\
\hline
\end{tabular}

BD; Bulk Density, $\mathrm{CaCO}_{3}$; Lime, OM; Organic matter, EC; Electrical conductivity

A mechanical analysis of the soils was performed using a hydrometer method and moisture content at $0.1,0.33,0.5$ and 15 bar-determined by using Pressure Plate Apparatus (Demiralay 1993). The pH (Kacar 2009) and electrical conductivity (EC) (US Salinity Laboratory Staff 1954) were determined in a 1:1 soil-water suspension. The percentage of calcium carbonate equivalent $\left(\mathrm{CaCO}_{3} \%\right)$ was recorded using a Scheibler calcimeter, and the organic matter content measured by the Walkley Black method (Kacar 2009). The bulk density and moisture contents were determined according to Demiralay (1993). Minitab 16 statistical software was used to obtain models for moisture constants and to determine the significance levels. The normal distribution of the data was checked by the Kolmogorov-Smirnov test. Stepwise regression equations were used with all parameters (sand, silt, clay, $\mathrm{CaCO}_{3}$, bulk density, organic matter and penetration resistance) as vary selection methods. In the 
evaluation of the regression equations, the coefficient of determination $\left(\mathrm{R}^{2}\right)$, the root means square error (RMSE) and the mean error (ME) were used (as given Equation 1). These formulas are also widely used in the literatures (Qiao et al. 2018; Santra et al. 2018).

$$
\mathrm{R}^{2}=1-\frac{\sum(y i-Y)^{2}}{\sum(y i-y)^{2}} \quad \mathrm{RMSE}=\sqrt{\frac{\sum(\mathrm{Xg}-\mathrm{Xt})^{2}}{\mathrm{n}}} \quad \mathrm{ME}=\sum_{\mathrm{i}=1}^{\mathrm{n}} \frac{(\mathrm{Xg}-\mathrm{Xt})}{\mathrm{n}}
$$

The $y i$ term used in the equation is the experimentally determined value, $Y$ is the calculated value from the regression equation, $y$ is the average of the experimental data, $\mathrm{Xg}$ is the actual value, $\mathrm{Xt}$ is the estimated value and $\mathrm{n}$ is the number of samples. The properties of the soil used in the testing phase of the models are given in Table 2.

Table 2- Properties of soil used in the models testing phase

\begin{tabular}{llccccccccccc}
\hline \multirow{2}{*}{ Soil group } & & $\begin{array}{c}\text { BD } \\
\mathrm{gr} \mathrm{cm}^{-3}\end{array}$ & $\begin{array}{c}\text { Clay } \\
\%\end{array}$ & $\begin{array}{c}\text { Silt } \\
\%\end{array}$ & $\begin{array}{c}\text { Sand } \\
\%\end{array}$ & $\begin{array}{c}0.1 \\
\text { bar }(\%)\end{array}$ & $\begin{array}{c}0.33 \\
\text { bar }(\%)\end{array}$ & $\begin{array}{c}0.5 \\
\text { bar }(\%)\end{array}$ & $\begin{array}{c}15 \\
\text { bar }(\%)\end{array}$ & $\begin{array}{c}\text { CaCO3 } \\
\%\end{array}$ & $\begin{array}{c}\text { OM } \\
\%\end{array}$ \\
\hline \multirow{3}{*}{ Sandy } & Minimum & 1.21 & 5.20 & 7.80 & 78.10 & 11.60 & 8.29 & 5.95 & 4.35 & 2.55 & 1.05 \\
& Maximum & 1.62 & 10.10 & 16.70 & 84.80 & 16.20 & 13.84 & 12.20 & 6.81 & 9.20 & 2.81 \\
& Mean & 1.39 & 8.01 & 11.34 & 80.66 & 13.77 & 11.71 & 9.78 & 5.38 & 5.45 & 1.87 \\
\hline \multirow{4}{*}{ Loamy } & Minimum & 1.21 & 12.50 & 13.90 & 21.31 & 20.12 & 17.37 & 14.10 & 8.95 & 2.11 & 1.3 \\
& Maximum & 1.61 & 38.94 & 47.29 & 69.60 & 29.30 & 27.71 & 26.60 & 16.99 & 22.33 & 3.59 \\
& Mean & 1.42 & 26.46 & 31.67 & 41.86 & 25.22 & 22.53 & 20.33 & 12.54 & 8.44 & 2.11 \\
\hline \multirow{3}{*}{ Clay } & Minimum & 1.21 & 40.40 & 12.10 & 9.37 & 29.30 & 26.60 & 23.10 & 15.16 & 1.22 & 1.17 \\
& Maximum & 1.54 & 62.51 & 41.14 & 35.38 & 35.45 & 31.95 & 28.45 & 19.94 & 15.54 & 3.82 \\
& Mean & 1.36 & 52.71 & 28.54 & 18.75 & 32.41 & 29.39 & 26.54 & 17.62 & 6.47 & 1.97 \\
\hline
\end{tabular}

BD; Bulk Density, OM; Organic matter, $\mathrm{CaCO}_{3}$; Lime

\section{Results and Discussion}

The moisture constants estimation models obtained for different textured groups are given in Table 3 . The coefficient of determination $\left(\mathrm{R}^{2^{* *}}\right)$, root mean square error (RMSE) and mean error (ME) values were used in the evaluation of the suitability of the models that are given in Table 3. The coefficient of determination ranged from 0.22 to 0.64 for different soil groups. The $\mathrm{R}^{2 * *}$ values were determined to be at low levels during the test phase of the models obtained for sandy soils. This situation, which is often encountered in different prediction models, is often related to the variability in effective soil characteristics. The lowest RMSE and ME values were determined for the 0.1 bar gravimetric moisture content $(1.16,0.85 \%)$ and 15 bar volumetric moisture content $(1.23,0.91 \%)$ prediction models. The RMSE and ME values were increased from 0.1 bar to 15 bar for the sandy soils. In the study by Silva et al. (2015), the $\mathrm{R}^{2}$ values were found to be 0.41 to 0.73 for 0.33 bar, and 0.58 to 0.75 for the 15 bar moisture content estimation models. In another similar study, the $\mathrm{R}^{2}$ value obtained was found to be between 0.23 and 0.85 for moisture constants (Mohanty et al. 2014), which is like in this study. In the comparison of the validity of the estimation models according to soil groups, the highest $\mathrm{R}^{2^{* *}}$ values $(0.54-0.64)$ were obtained for the loamy soils (Table 3 ). The models obtained for the loamy soils could estimate the actual moisture content with about a $60 \%$ accuracy. In the study by Keshavarzi et al. (2010), the test phase of the model constructed to estimate the field capacity and wilting point, the $\mathrm{R}^{2}$ values were 0.68 and 0.64 , and the RMSE values were $4.46 \%$ and $5.21 \%$, respectively. In a study conducted by Esmaeelnejad et al. (2015), the $\mathrm{R}^{2}$ values were 0.79 and 0.87 for the 0.33 and 15 bar prediction models, respectively, and the $\mathrm{R}^{2}$ values obtained in the test phase were 0.68 and 0.77 , respectively. It was evident that the test phase $\mathrm{R}^{2}$ values obtained in the present study approximately match the values in published literature. The ME values changed from 1.53 to $5.11 \%$ and RMSE from 1.23 to $3.08 \%$ for loamy soil groups. In this group, The $\mathrm{R}^{2}$ was high, The RMSE and ME were low because the number of samples was higher than other groups. It is known that the soils in the region were medium structure. The relationships between the predicted and actual moisture content in the clay soils were determination ranged from 0.48 to 0.54 for the different moisture tensions. Gülser (2004) determined the $\mathrm{R}^{2}$ of the prediction model for the field capacity to be 0.85 , while the difference between the predicted and actual value was 0.92. However, in the study, different soil properties (sand, clay, organic matter, EC, porosity) were evaluated for the estimation of moisture constants, and predictability was determined by increasing the number of variables included in the model. In the clay soils, the changes in RMSE, ME and $\mathrm{R}^{2 * *}$ were close for all soil moisture tensions. When the gravimetric moisture contents generally were used, higher $\mathrm{R}^{2^{* * *}}$ and lower RMSE and ME values were obtained in all soil groups and moisture tensions. Gravimetric moisture content determinations models were more stable than volumetric moisture content models, because soil bulk density could variable. Busscher (1990) used the moisture content gravimetrically in his models to estimate the penetration resistance by using the bulk density and water content of the saturation and soil moisture content properties. The similarity between the soils used in the testing phase and those used in the model was the reason for the high correlation between the estimated and actual values. Many researchers report that prediction models are not available for each soil group due to the different characteristics of soils (Mohawesh 2013; Abdelbaki 2018). It was determined that there was no consistent change in the models due to increased moisture tension for $\mathrm{R}^{2}$ values. 
Table 3- Moisture prediction models

\begin{tabular}{|c|c|c|c|c|c|}
\hline Soil groups & $\begin{array}{l}\text { Moisture tension } \\
\text { (bar) }\end{array}$ & Models & $\begin{array}{c}R M S E \\
\%\end{array}$ & $\begin{array}{c}M E \\
\%\end{array}$ & $R^{2 * *}$ \\
\hline \multirow{4}{*}{$\begin{array}{l}\text { Sandy } \\
\text { (M) }\end{array}$} & 0.1 & $\mathrm{Y}: 16.494\left[\operatorname{Pr}_{x} \exp ((\mathrm{x}-0.15) / 0.112)\right]^{0.2671}$ & 1.16 & 0.85 & 0.46 \\
\hline & 0.33 & $\mathrm{Y}: 12.362\left[\operatorname{Pr}_{\mathrm{x}} \exp ((\mathrm{x}-0.12) / 0.112)\right]^{0.4511}$ & 2.22 & 1.88 & 0.32 \\
\hline & 0.5 & $Y: 9.5247\left[\operatorname{Pr}_{x} \exp ((x-0.10) / 0.112)\right]^{0.4288}$ & 2.76 & 2.27 & 0.22 \\
\hline & 15 & $\mathrm{Y}: 3.2231\left[\operatorname{Pr}_{\mathrm{x}} \exp ((\mathrm{x}-0.055) / 0.112)\right]^{0.7353}$ & 2.74 & 2.45 & 0.42 \\
\hline \multirow{4}{*}{$\begin{array}{l}\text { Loamy } \\
\text { (M) }\end{array}$} & 0.1 & $\mathrm{Y}: 25.869\left[\operatorname{Pr}_{\mathrm{x}} \exp ((\mathrm{x}-0.24) / 0.172)\right]^{0.2617}$ & 1.63 & 1.77 & 0.61 \\
\hline & 0.33 & $Y: 21.113\left[\operatorname{Pr}_{x} \exp ((x-0.21) / 0.172)\right]^{0.3645}$ & 1.46 & 1.75 & 0.60 \\
\hline & 0.5 & $\mathrm{Y}: 17.848\left[\operatorname{Pr}_{\mathrm{x}} \exp ((\mathrm{x}-0.19) / 0.172)\right]^{0.411}$ & 1.32 & 1.53 & 0.64 \\
\hline & 15 & $Y: 7.5323\left[\operatorname{Pr}_{x} \exp ((x-0.11) / 0.172)\right]^{0.4573}$ & 1.90 & 2.05 & 0.59 \\
\hline \multirow{4}{*}{$\begin{array}{l}\text { Clay } \\
(\mathrm{M})\end{array}$} & 0.1 & $\mathrm{Y}: 31.508\left[\operatorname{Pr}_{\mathrm{x}} \exp ((\mathrm{x}-0.30) / 0.126)\right]^{0.125}$ & 1.75 & 1.50 & 0.54 \\
\hline & 0.33 & $Y: 27.256\left[\operatorname{Pr}_{x} \exp ((x-0.26) / 0.126)\right]^{0.1545}$ & 1.78 & 1.55 & 0.50 \\
\hline & 0.5 & $\mathrm{Y}: 23.67\left[\operatorname{Pr}_{\mathrm{x}} \exp ((\mathrm{x}-0.24) / 0.126)\right]^{0.1748}$ & 1.65 & 1.47 & 0.52 \\
\hline & 15 & $Y: 11.769\left[\operatorname{Pr}_{x} \exp ((x-0.15) / 0.126)\right]^{0.3178}$ & 1.59 & 1.44 & 0.54 \\
\hline \multirow{4}{*}{$\begin{array}{l}\text { Sandy } \\
(\Theta)\end{array}$} & 0.1 & $\mathrm{Y}: 22.88\left[\operatorname{Pr}_{\mathrm{x}} \exp ((\mathrm{x}-0.21) / 0.153)\right]^{0.2494}$ & 2.88 & 2.23 & 0.39 \\
\hline & 0.33 & $Y: 17.203[\operatorname{Pr} x \exp ((x-0.17) / 0.153)]^{0.4563}$ & 1.47 & 1.08 & 0.39 \\
\hline & 0.5 & $Y: 13.157\left[\operatorname{Pr}_{x} \exp ((x-0.14) / 0.153)\right]^{0.4725}$ & 1.31 & 1.06 & 0.39 \\
\hline & 15 & $\mathrm{Y}: 5.67737\left[\operatorname{Pr}_{\mathrm{x}} \exp ((\mathrm{x}-0.08) / 0.153)\right]^{0.4028}$ & 1.23 & 0.91 & 0.39 \\
\hline \multirow{4}{*}{$\begin{array}{l}\text { Loamy } \\
(\Theta)\end{array}$} & 0.1 & $\mathrm{Y}: 35.248\left[\operatorname{Pr}_{\mathrm{x}} \exp ((\mathrm{x}-0.32) / 0.238)\right]^{0.248}$ & 3.49 & 5.11 & 0.54 \\
\hline & 0.33 & $\mathrm{Y}: 28.5537\left[\operatorname{Pr}_{\mathrm{x}} \exp ((\mathrm{x}-0.28) / 0.238)\right]^{0.3742}$ & 3.08 & 4.92 & 0.54 \\
\hline & 0.5 & $Y: 24.114\left[\operatorname{Pr}_{x} \exp ((x-0.26) / 0.238)\right]^{0.4166}$ & 1.23 & 1.70 & 0.58 \\
\hline & 15 & $Y: 9.9342\left[\operatorname{Pr}_{x} \exp ((x-0.15) / 0.238)\right]^{0.4858}$ & 3.49 & 5.11 & 0.54 \\
\hline \multirow{4}{*}{$\begin{array}{r}\text { Clay } \\
(\Theta)\end{array}$} & 0.1 & $\mathrm{Y}: 42.571\left[\operatorname{Pr}_{\mathrm{x}} \exp ((\mathrm{x}-0.39) / 0.178)\right]^{0.1665}$ & 2.36 & 1.99 & 0.52 \\
\hline & 0.33 & $Y: 36.387\left[\operatorname{Pr}_{x} \exp ((x-0.35) / 0.178)\right]^{0.1948}$ & 2.97 & 2.53 & 0.48 \\
\hline & 0.5 & $\mathrm{Y}: 31.203\left[\operatorname{Pr}_{x} \exp ((\mathrm{x}-0.32) / 0.178)\right]^{0.2292}$ & 2.15 & 1.81 & 0.51 \\
\hline & 15 & $\mathrm{Y}: 16.04\left[\operatorname{Pr}_{\mathrm{x}} \exp ((\mathrm{x}-0.20) / 0.178)\right]^{0.2846}$ & 1.53 & 1.53 & 0.54 \\
\hline
\end{tabular}

$\Theta$; Models to be evaluated in case of using volumetric moisture content, M; Models to be evaluated in the case of gravimetric moisture content, Y; Moisture content $(\%), \mathrm{Pr}_{\mathrm{x}}$; Penetration resistance measured in the field $(\mathrm{MPa}), \mathrm{X} ;$ Moisture content of soil measured in the field $\left(\mathrm{kg} \mathrm{kg}^{-1}\right) /\left(\mathrm{cm}^{3} \mathrm{~cm}^{-3}\right), * * ; \mathrm{coefficient}^{*}$ determination indicating the relationship between actual data and predictions

The multivariate regression equations obtained by using sand, silt, clay, organic matter, percentage of $\mathrm{CaCO}_{3}$ and bulk density properties of soils are given in Table 4. It was found that the relationship between the models obtained for all moisture tensions was statistically significant $(\mathrm{P}<0.05)$. The values for $\mathrm{R}^{2^{*}}$ were determination from 0.27 to 0.79 , for the different soil moisture tensions and soil texture groups. The determination accuracy of this moisture tension model was $79 \%$ by using organic matter, penetration resistance properties, bulk density clay, sand and $\mathrm{CaCO}_{3}$ for sandy soil 0.1 bar moisture tension. Gülser (2004) estimated the field capacity and wilting point by using sand, silt, clay, organic matter, EC and porosity properties, and the validity of the models were calculated to be $85 \%$ and $96 \%$. In contrast to the present study, it was considered that the inclusion of EC and porosity properties in the model increased the accuracy of estimation. The loamy soil group demonstrated the highest predictability for all moisture tensions across the soil groups. The $\mathrm{R}^{2 * *}, \mathrm{RMSE}$ and ME values for the test phase of the alternative models obtained are given in Table 4. In the general regression models for sandy soil group, the RMSE values were found to be between $0.78 \%$ and $3.55 \%$. The ME value was 0.67 to $3.44 \%$ and the $\mathrm{R}^{2^{* *}}$ value was 0.60 to 0.75 . The $\mathrm{R}^{2}$ obtained during the model and the $\mathrm{R}^{2 * *}$ obtained in the test stage were found to be like each other. The relationship between the actual values and the predicted values were generally determined at a high level of accuracy by using general regression models for the sandy soils. For moisture contents of 0.33 and 15 bar, the $\mathrm{R}^{2^{* *}}$ values were quite close to each other, but RMSE and ME values were lower for the 15 bar estimation model. The $\mathrm{R}^{2^{*}}$ values were determined to be 0.72 , $0.77,0.71$ and 0.74 for the loamy soils, respectively. These estimation models, which were statistically significant $(\mathrm{P}<0.01)$, provided approximately $70 \%$ accuracy at all moisture tensions. In a study to estimate soil moisture constants Cemek et al. (2004) it was reported that the models generated using parameters such as particle size and bulk density would increase the prediction accuracy. In the general regression models for loamy soil groups, the RMSE values were found to be between 1.38 $\%$ and $2.44 \%$. The ME value was 1.19 to $2.15 \%$ and the $\mathrm{R}^{2^{* *}}$ value was 0.10 to 0.82 . While the $\mathrm{R}^{2^{* *}}$ value of the prediction models created for the moisture content of 15 bar was high, the $\mathrm{R}^{2^{* *}}$ value obtained in the test stage was determined at very low. Although there was a difference of about $2 \%$ in the RMSE and ME values, the $\mathrm{R}^{2^{* *}}$ was found to be so low. It shows that there was no regular variation between the predicted and actual values. The relationships between the estimated and actual values for the clay soils were found to be quite low in general regression models. In the context of regression equations obtained according the stepwise method are given Table 5. Increases in moisture content had a general tendency to decrease $\mathrm{R}^{2 *}$ values for sandy soil. The penetration resistance and the $\mathrm{CaCO}_{3}$ percentage were the main sources at low moisture tension, while the sand and silt percentage were found to predominantly affect moisture content at 15 bar. For moisture content 
maintained at a soil moisture tension of 0.1 bar, the value of $\mathrm{R}^{2 *}(0.62)$ obtained by using only penetration resistance, increased by about $11 \%$ with the inclusion of the $\mathrm{CaCO}_{3}$ content. In dry soils, the adherence of the particles to each other is high. As the moisture content increased in the soil, the bond between the particles was weakened by the water layer, thus decreasing the penetration resistance due to the reduced friction. Aggregation is a factor that increases the water retention property of the soil (Zibilske \& Bradford 2007). The increase in the $\mathrm{CaCO}_{3}$ content affected aggregation (Y1lmaz et al. 2005), this explained the relationship between water retention and $\mathrm{CaCO}_{3}$. The estimation accuracy of the model was found to be $78 \%$ by using penetration resistance at 0.1 bar along with the percentage of $\mathrm{CaCO}_{3}$ and silt. For moisture content maintained at a tension of 0.33 bar, the predictive accuracy of the models with penetration resistance was only $54 \%$. An increase of $8 \%$ was observed by adding the $\mathrm{CaCO}_{3}$ content to the model (Table 5). It was clear that the sand fraction was very effective in the sandy group. In the model where sand and silt were present at 15 bar, the $\mathrm{R}^{2 *}$ value was determined to be $58 \%$, and the $\mathrm{CaCO}_{3}$ contribution was not found to be very effective. The RMSE, ME and $\mathrm{R}^{2 * *}$ values were determined to be between 0.91 to $4.16 \%, 0.78$ to $4.06 \%$ and 0.01 to 0.51 for sandy soil, respectively. The accuracy of the 0.5 bar moisture content prediction models was determined at very low levels. It shows that there was no regular variation between the predicted and actual values. The minimum RMSE $(0.91 \%)$ and $\mathrm{ME}(0.78 \%)$ determined at 15 bar. Because the wilting point contents of soils were narrow range. In the loamy soil group prediction models, the maximum $\mathrm{R}^{2^{*}}$ values were determined to be $0.71,0.77,0.69$ and 0.74 for soil moisture tensions of $0.1,0.33,0.5$ and 15 bar, respectively (Table 5). The RMSE, ME and $\mathrm{R}^{2^{* *}}$ values were determined to be between 1.54 to $5.08 \%, 1.17$ to $3.97 \%$ and 0.63 to 0.82 in the model testing phase, respectively. The $\mathrm{R}^{2^{*}}$ value was found to be between 54 to $71 \%$ for all moisture tensions when using only the penetration resistance as the independent variable. Penetration resistance ensured accuracy levels of $65 \%$ and $71 \%$ for soil moisture tensions of 0.1 and 0.33 bar. In addition to penetration resistance, the inclusion of organic matter content in the models resulted in an increase of approximately 5\%. With the further inclusion of silt, the accuracy of the models increased to $71 \%$ and $77 \%$. Relationship between organic material and water retention (Y1lmaz \& Alagöz 2008) was increased the $\mathrm{R}^{2^{*}}$. An increase of $5 \%$ and $7 \%$ was determined in the $\mathrm{R}^{2^{*}}$ values following the inclusion of the sand content for models at soil moisture tensions of 0.5 and 15 bar. The negative correlation between sand content and moisture content (Pan et al. 2012) has also shown an effect on models in this current study. It was observed that sand was more effective than organic material. The validity of the models for loamy soils were very high. As the number of samples was high, soil characteristics were different, and this affected the result. In the clay soil estimation models, the $\mathrm{R}^{2 *}$ values were found to be $0.37,0.33,0.21$ and 0.46 (Table 5). As the other soil groups, penetration resistance and bulk density were the most effective of the independent variables. In addition to penetration resistance, the bulk density added to the model resulted in an increase of about $8 \%$ (in $\mathrm{R}^{2^{*}}$ value) for the 15 bar moisture content estimation model. Minasny (2009), determined the $\mathrm{R}^{2}$ value to be 0.81 and 0.88 by using the sand content and bulk density properties of soil for the estimation of the field capacity. The RMSE, ME and $\mathrm{R}^{2 * *}$ values were determined to be between 1.57 to $1.96 \%, 1.29$ to $1.59 \%$ and 0.32 to 0.51 , respectively. The validity of the models was very low for clay soils. The distribution of soil samples is generally loamy texture. The clay soil texture groups are not very common in the region, the number of sampling was low. The more soil samples could increase the $\mathrm{R}^{2}$. In addition, the number of loamy texture group sample was high. Their relationships were higher than the other groups.

Table 4- Regression equations for moisture constants according to soil groups

\begin{tabular}{|c|c|c|c|c|c|}
\hline $\begin{array}{c}\text { Moisture } \\
\text { tension } \\
\text { (bar) }\end{array}$ & Sandy Soil & $R^{2^{*}}$ & $R M S E$ & $M E$ & $R^{2 * *}$ \\
\hline 0.1 & $=19.4+0.21 \mathrm{a}-0.114 \mathrm{~b}-0.107 \mathrm{c}+0.413 \mathrm{~d}+0.626 \mathrm{e}+4.44 \mathrm{f}$ & 0.79 & 3.5 & 3.44 & 0.75 \\
\hline 0.33 & $=-3.6+4.20 \mathrm{a}-0.055 \mathrm{~b}+0.044 \mathrm{c}+0.536 \mathrm{~d}-0.24 \mathrm{e}+5.97 \mathrm{f}$ & 0.66 & 2.76 & 2.61 & 0.64 \\
\hline 0.5 & $=-7.9+5.8 \mathrm{a}+0.07 \mathrm{~b}+0.046 \mathrm{c}+0.406 \mathrm{~d}-0.33 \mathrm{e}+4.52 \mathrm{f}$ & 0.59 & 2.64 & 2.17 & 0.46 \\
\hline 15 & $=29-0.63 \mathrm{a}-0.169 \mathrm{~b}-0.274 \mathrm{c}+0.330 \mathrm{~d}-0.423 \mathrm{e}+0.182 \mathrm{f}$ & 0.64 & 0.78 & 0.67 & 0.60 \\
\hline \multicolumn{6}{|c|}{ Loamy Soil } \\
\hline 0.1 & $=13.429+0.63 \mathrm{a}+0.0157 \mathrm{~b}+0.0534 \mathrm{c}+0.0092 \mathrm{~d}+0.789 \mathrm{e}+8.01 \mathrm{f}$ & 0.72 & 2.44 & 2.03 & 0.45 \\
\hline 0.33 & $=11.4-0.89 a+0.0290 b+0.0580 c-0.0151 d+0.751 e+6.94 f$ & 0.77 & 2.38 & 2.15 & 0.43 \\
\hline 0.5 & $=9.55-0.87 \mathrm{a}+0.0486 \mathrm{~b}-0.0682 \mathrm{c}-0.0204 \mathrm{~d}+0.721 \mathrm{e}+5.23 \mathrm{f}$ & 0.71 & 1.38 & 1.19 & 0.82 \\
\hline 15 & $=3.78-0.17 \mathrm{a}+0.0631 \mathrm{~b}+0.0757 \mathrm{c}-0.0031 \mathrm{~d}+0.392 \mathrm{e}+1.29 \mathrm{f}$ & 0.74 & 2.43 & 2.02 & 0.10 \\
\hline \multicolumn{6}{|c|}{ Clay Soil } \\
\hline 0.1 & $=28-4.11 \mathrm{a}+0.0036 \mathrm{~b}+0.120 \mathrm{c}-0.0542 \mathrm{~d}+0.018 \mathrm{e}+4.53 \mathrm{f}$ & 0.48 & 4.22 & 3.72 & 0.13 \\
\hline 0.33 & $=26.6-1.95 \mathrm{a}+0.0105 \mathrm{~b}-0.09 \mathrm{c}-0.0230 \mathrm{~d}-0.558 \mathrm{e}+4.94 \mathrm{f}$ & 0.37 & 2.65 & 2.20 & 0.36 \\
\hline 0.5 & $=25.6-4.67 \mathrm{a}+0.0112 \mathrm{~b}+0.041 \mathrm{c}-0.0232 \mathrm{~d}-0.580 \mathrm{e}+3.91 \mathrm{f}$ & 0.27 & 1.86 & 1.62 & 0.33 \\
\hline 15 & $=19.7-6.55 a-0.0245 b-0.002 c-0.0186 d+0.267 e+2.12 f$ & 0.50 & 1.91 & 1.66 & 0.55 \\
\hline
\end{tabular}

* coefficient of determination obtained during the creation of models, ** coefficient of determination indicating the relationship between actual data and predictions 
Table 5- Stepwise regression equations for moisture constants according to soil groups

\begin{tabular}{|c|c|c|c|c|c|}
\hline $\begin{array}{l}\text { Moisture Tension } \\
\text { (bar) }\end{array}$ & Sandy Soil & & & & \\
\hline \multirow{5}{*}{0.1} & & $R^{2^{*}}$ & RMSE & $M E$ & $R^{2 * *}$ \\
\hline & ${ }^{1}=10.976+5.64 \mathrm{a}$ & 0.62 & \multirow{3}{*}{4.16} & \multirow{3}{*}{4.06} & \multirow{3}{*}{0.51} \\
\hline & ${ }^{2}=9.965+5.57 a+0.49 b$ & 0.74 & & & \\
\hline & $\begin{array}{l}{ }^{3}=9.430+4.54 a+0.41 b+ \\
0.121 c\end{array}$ & 0.78 & & & \\
\hline & \multicolumn{5}{|c|}{ a:penetration resistance $(\mathrm{MPa}), \mathrm{b}: \mathrm{CaCO}_{3} \%$, c: silt $\%$} \\
\hline \multirow{3}{*}{0.33} & ${ }^{1}=7.105+5.2 \mathrm{a}$ & 0.54 & \multirow{2}{*}{2.98} & \multirow{2}{*}{2.78} & \multirow{2}{*}{0.44} \\
\hline & ${ }^{2}=6.075+5.2 \mathrm{a}+0.47 \mathrm{~b}$ & 0.62 & & & \\
\hline & \multicolumn{5}{|c|}{ a:penetration resistance $(\mathrm{MPa}), \mathrm{b}: \mathrm{CaCO}_{3} \%$} \\
\hline \multirow{4}{*}{0.5} & ${ }^{1}=6.246+3.38 \mathrm{a}$ & 0.37 & \multirow{3}{*}{2.00} & \multirow{3}{*}{1.60} & \multirow{3}{*}{0.01} \\
\hline & ${ }^{2}=-2.930+4.10 a+5.9 b$ & 0.51 & & & \\
\hline & $\begin{array}{l}3=-4.032+4.17 a+6.1 b+ \\
0.37 c\end{array}$ & 0.58 & & & \\
\hline & \multicolumn{5}{|c|}{ a: penetration resistance (MPa), b:bulk density $\left(\mathrm{g} \mathrm{cm}^{-3}\right), \mathrm{c}: \mathrm{CaCO}_{3} \%$} \\
\hline \multirow{4}{*}{15} & ${ }^{1}=28.08-0.275 \mathrm{a}$ & 0.48 & \multirow{4}{*}{0.91} & \multirow{4}{*}{0.78} & \multirow{3}{*}{0.43} \\
\hline & ${ }^{2}=16.775-0.158 a+0.145 b$ & 0.58 & & & \\
\hline & $\begin{array}{l}3=13.124-0.122 \mathrm{a}+0.150 \mathrm{~b} \\
+0.28 \mathrm{c}\end{array}$ & 0.59 & & & \\
\hline & \multicolumn{3}{|l|}{ a: sand $\%$, b:silt $\%$, c: $\mathrm{CaCO}_{3} \%$} & & \\
\hline \multicolumn{6}{|c|}{ Loamy Soil } \\
\hline \multirow{4}{*}{0.1} & ${ }^{1}=16.08+10.14 \mathrm{a}$ & 0.65 & \multirow{3}{*}{1.70} & \multirow{3}{*}{1.25} & \multirow{3}{*}{0.76} \\
\hline & ${ }^{2}=14.91+8.94 \mathrm{a}+1.06 \mathrm{~b}$ & 0.69 & & & \\
\hline & ${ }^{3}=14.53+8.06 a+0.82 b+0.050 c$ & 0.71 & & & \\
\hline & \multicolumn{5}{|c|}{ a: penetration resistance $(\mathrm{MPa})$, b:organic matter \%, c:silt \% } \\
\hline & ${ }^{1}=12.28+8.59 \mathrm{a}$ & 0.71 & & & \\
\hline 0.33 & ${ }^{2}=11.17+7.60 a+1.07 b$ & 0.75 & 1.60 & 1.44 & 0.76 \\
\hline & ${ }^{3}=10.75+6.88 \mathrm{a}+0.83 \mathrm{~b}+0.052 \mathrm{c}$ & 0.77 & & & \\
\hline & a: penetration resistance $(\mathrm{MPa}$ & c matte & & & \\
\hline & ${ }^{1}=11+6.68 \mathrm{a}$ & 0.62 & & & \\
\hline 0.5 & ${ }^{2}=15.59+5.62 \mathrm{a}-0.072 \mathrm{~b}$ & 0.68 & 154 & 1.17 & 082 \\
\hline & $\begin{array}{l}3=13.76+5.25 a-0.057 b+ \\
0.78 c\end{array}$ & 0.69 & & & \\
\hline & a: penetration resistance $(\mathrm{MPa}$ & 6, c: or & & & \\
\hline & ${ }^{1}=7.44+1.79 \mathrm{a}$ & 0.56 & & & \\
\hline 15 & ${ }^{2}=11.595+1.36 \mathrm{a}-0.080 \mathrm{~b}$ & 0.73 & 5.08 & 3.97 & 0.63 \\
\hline & ${ }^{3}=1.29+8.07 a-0.071 b+0.41 c$ & 0.74 & & & \\
\hline & a: penetration resistance $(\mathrm{MPa}$ & $\%, \mathrm{c:}: \mathrm{o}$ & & & \\
\hline & & & & & \\
\hline 0.1 & ${ }^{1}=26.44+5.1 \mathrm{a}$ & 0.37 & 1.68 & 1.43 & 0.51 \\
\hline 0.33 & ${ }^{1}=22.69+4.5 \mathrm{a}$ & 0.33 & 1.96 & 1.59 & 0.32 \\
\hline 0.5 & ${ }^{1}=20.03+3.6 \mathrm{a}$ & 0.21 & 1.57 & 1.29 & 0.32 \\
\hline & ${ }^{1}=10.65+2.04 \mathrm{a}$ & 0.38 & & & \\
\hline 15 & ${ }^{2}=17.64+2.29 a-5.7 b$ & 0.46 & 1.57 & 1.29 & 0.32 \\
\hline & a: penetration resistance $(\mathrm{MPa}$ & density & & & \\
\hline
\end{tabular}

* coefficient of determination obtained during the creation of models, ** coefficient of determination indicating the relationship between actual data and predictions

\section{Conclusions}

The main scope of this study was to predict moisture constants through penetration resistance. Then, in the regression models obtained using some other properties of the soils. The most accurate relationships predict moisture constants through penetration resistance were determined for the loamy soils at all soil moisture tensions. The 0.1 bar moisture content estimation 
model of the sandy soils indicated a $75 \%$ accuracy in general linear regression. In the loamy soil group can be predicted at an accuracy of $63 \%$ to $82 \%$ in stepwise regression models. In the clay soils group, the highest $\mathrm{R}^{2 * *}$ and the lowest RMSE and ME values were found to be at 15 bar. In addition, it was found that the most effective parameter included in the model as an independent variable for all soil groups was the penetration resistance of the models formed using the stepwise method. As a result of testing alternative models, the recommendation for the estimation of field capacity was to use the 0.1 bar general regression model for sandy soils, and the 0.33 bar stepwise model for loamy soils. Consequently, there were differences in the reliability of the models according to the texture of the groups. More accurate relationships were obtained for the loamy soils. Moisture constants can be estimated by using penetration resistance, but more reliable models are produced by adding organic material, sand and silt to the models.

\section{Acknowledgments}

This study was produced from a PhD thesis of first author. I would like to thank Süleyman Demirel University Academic Staff Training Program Department for supporting my thesis with OYP04947-DR-13 project.

\section{References}

Abdelbaki A M (2018). Evaluation of pedotransfer functions for predicting soil bulk density for US soils. Ain Shams Engineering Journal 9(4): 1611-1619 https://doi.org/10.1016/j.asej.2016.12.002

Bahtiyar M (1978). Soil water, water retention in the soil and moisture tension. Atatürk University Journal of Agricultural Faculty 9(4): 105119 (In Turkish)

Busscher W J (1990). Adjustment of flat- tipped penetrometer resistance data to a common water content. Retrieved in March, 12, 2018 from http://naldc. nal.usda. gov/download/ 18014/PDF https://doi.org/10.13031/2013.31360

Cemek B, Meral R, Apan M \& Merdun H (2004). Pedotransfer function fort the estimation of the field capacity and permanent wilting point. Pakistan Journal of Biological Science 7(4): 535-541 https://doi.org/10.3923/pjbs.2004.535.541

Demiralay M (1993). Soil Physical Analysis. Atatürk University Faculty of Agriculture Publications, No: 143 Turkey (In Turkish)

Esmaeelnejad L, Ramezanpour H, Seyedmohammadi J \& Shabanpour M (2015). Selection of a suitable model for the prediction of soil water content in north of Iran. Spanish Journal of Agricultural Research 13(1):1202 https://doi.org/10.5424/sjar/2015131-6111

Gülser C (2004). Determination of field capacity and permanent wilting point with pedotransfer functions related to soil physical and chemical properties. Journal of Faculty of Agriculture Ondokuz Mayls University 19(3): 19-23 (in Turkish with an abstract in English)

Kacar B (2009). Soil Analysis. Nobel Publication No: 1387 Ankara (In Turkish)

Keshavarzi A, Sarmadian F, Sadeghnejad M \& Pezeshki P (2010). Developing pedotransfer functions for estimating some soil properties using artificial neural network and multivariate regression approaches. Proenvironment Promediu 3: 322-330

Minasny B (2009) Prediction of the water content at field capacity from disturbed soil samples. Retrieved in May, 12, 2017 from http://soilresearch.com/sr/wpcontent/uploads/2010/05/fieldcapacity_disturbed_samples .pdf

Mohanty M, Sinha N K, Painuli D K, Bandyopadhyay K K, Hatı K, Reddy K S \& Chaudhary R S (2014). Pedotransfer functions for estimating water content at field capacity and wilting point of Indian soils using particle size distribution and bulk density. Journal of Agricultural Physics 14(1): 1-9

Mohanty M, Nishan K, Sinha D K, Painuli K K, Bandyopadhyay K M, Hati K \& Sammi Reddy Chaudhary R S (2015). Modelling soil water contents at field capacity and permanent wilting point using artificial neural network for Indian soils. National Academy Science Letter 38(5): 373-377 https://doi.org/10.1007/s40009-015-0358-4

Mohawesh O E (2013). Assessment of pedotransfer functions (ptfs) in predicting soil hydraulic properties under arid and semi arid environments. Jordan Journal of Agricultural Sciences 9(4): 475-491

Negiş H, Şeker C, Gümüş İ, Özaytekin H H, Atmaca E \& Karaca Ü (2016). Determination of penetration resistance in sugar beet farming. Nevsehir Journal of Science and Technology pp. 272-279 (in Turkish with an abstract in English)

Pan W, Boyles R P, White J G \& Heitman J L (2012) Characterizing soil physical properties for soil moisture monitoring with the north carolina environment and climate observing network. Journal of Atmospheric and Oceanic Technology 29(7): 933-943 https://doi.org/10.1175/jtech-d-11-00104.1

Qiao J, Zhu Y, Jia X, Huang L \& Shao M A (2019) Pedotransfer functions for estimating the field capacity and permanent wilting point in the critical zone of the Loess Plateau, China. Journal of Soils and Sediments 19(1):140-147 https://doi.org/10.1007/s11368-018-2036-X

Santra P, Kumar M, Kumawat R N, Painuli D K, Hati K M, Heuvelink G B M \& Batjes N H (2018) Pedotransfer functions to estimate soil water content at field capacity and permanent wilting point in hot Arid Western India. Journal of Earth System Science 127(3): 1-16 https://doi.org/10.1007/s12040-018-0937-0

Silva E D, Curi N, Ferreira M M, Volpato M M L, Santos W J R D \& Silva S H G (2015). Pedotransfer functions for water retention in the main soils from the Brazilian coastal plains. Ciência e Agrotecnologia 39(4): 331-338 https://doi.org/10.1590/s141370542015000400003

Soil Survey Manual (1993). Soil survey division staff, United States department of agriculture

Şeker C (1997). The effect of water content on the penetration resistance of different soils, and regression models. Turkish Journal of Agriculture and Forestry 23(2): 467-471 (in Turkish with an abstract in English)

Touil S, Degre A \& Chabaca M N (2016). Sensitivity analysis of point and parametric pedotransfer functions for estimating water retention of soils in Algeria. Soil 2(4):647 https://doi.org/10.5194/soil-2-647-2016

Turgut B, Aksakal E L, Öztaş T \& Babagil G E (2008). Defining partial effect coefficients of soil properties affecting on soil penetration resistanceusing multiple regression analysis. Journal of Faculty of Agriculture Atatürk University 39(1): 115-121 (in Turkish with an abstract in English)

Turgut B, Öztaş T \& Aksakal E L (2010). Defining direct and indirect effect of some soil properties on soil penetration resistance. Journal of the Faculty of Agriculture Süleyman Demirel University 5(2): $45-53$ (in Turkish with an abstract in English)

U.S Salinity Laboratory Staff (1954). Diagnosis and Improvement of Salina and Alkali Soils. Agricultural Handbook 60, USDA 
Yılmaz E, Alagöz Z \& Öktüren F (2005). Aggregate formation and stability in soil. Selcuk Journal of Agriculture and Food Sciences 19(36): $78-86$

Y1lmaz E \& Alagöz Z (2008). Relation between soil water and organic matter. Turkish Journal of Scientific Reviews 1(2): 15-21

Zibilske L M \& Bradford J M (2007). Soil aggregation, aggregate carbon and nitrogen, and moisture retention induced by conservation tillage. Soil Science Society of America Journal 71(3): 793-802 https://doi.org/10.2136/sssaj2006.0217

(c) (1)

(C) 2021 by the authors. Licensee Ankara University, Faculty of Agriculture, Ankara, Turkey. This article is an open access article distributed under the terms and conditions of the Creative Commons Attribution (CC BY) license (http://creativecommons.org/licenses/by/4.0/). 